\title{
Identifying the Effect of Direct Tax Exemption in Attracting Private Investment in Industrial Sections in Industrial Towns
}

\author{
${ }^{1}$ Mohammad Sadeghi Sayyah
}

2Hamid Jamshidi

${ }^{1}$ Department of Accounting, Islamshahr Branch, Islamic Azad University, Islamshahr, Iran 2Department of Accounting, Islamshahr Branch, Islamic Azad University, Islamshahr, Iran

Doi:10.5901/mjss.2016.v7n4p669

\section{Abstract}

The main purpose of doing this research is to investigate the effect of tax exemption the topic of provision 132 of the law of direct taxes on increasing in investment in private sector in industry (industrial towns). For this reason, three factors of time covering of tax exemption, limitation of location area to take advantage of tax exemption and the effect of calculated resource of exemption in increasing the investment in private sector in industry was also investigated. The research method was survey and the needed data were gathered through questionnaire. The research sample included 96 observations and the method of testing the hypotheses was through comparing the means of single sample society. The results of data analysis showed that tax exemption of provision 132 laws of direct taxes and its factors including time covering, location area and the resource of calculating tax exemption has a meaningful effect on increasing the attraction of private investors in industrial towns.

Keywords: tax exemption, the law of direct taxes, time covering of tax exemption, location area of tax exemption, the resource of tax exemption

\section{Introduction}

Every economy needs investment in order to meet the element of capital and investment can be ideal when the present organizations of the society can provide the security that is needed for investment. In today's literature of investment especially the external direct investment, the topics of investment security and guarantee of the investor's rights have attracted a great attention to themselves. The process of private and state investment indicates some fluctuations in the role of these two kinds of investment in forming the capital. Private and state sectors have different motives. The private sector seeks for maximizing the profit and following that maximizing the present net value of the project and follows doing each project and plan in investment as much as possible in a rational decision, and it can explain why private investor reacts quickly to the political and economic events. So, the main purpose of this research is to investigate the effect of tax exemption of provision 132 of the law of tax exemption in increasing the investment in private sector in industry (industrial towns). Therefore, the research hypotheses are as follows:

\section{Main Questions}

Q1: Has the tax exemption of the provision 132 of direct tax exemption had any influence in increasing the amount of investment in private sector in industrial towns?

Q2: Has the tax exemption of the provision 132 of direct tax exemption had any influence in increasing the amount of investment in private sector in industrial towns in less developed areas?

\section{Secondary Questions}

Q3:Does improving the time covering of tax exemption of the provision 132 of direct tax exemption from the government increase private investment in industrial sectors?

Q4: Does the industrial sites located in the areas identified in part 2 of provision 132 of the law of direct taxes of tax exemption of the mentioned provision increase private investment in industrial sectors?

Q5: Will improving the source of calculating exemption of the provision 132 of the law of tax exemption of the profit liable to the identified tax by the office of tax issues cause the efficient use of the mentioned exemption? 


\section{Literature Review}

Pajooyan and Khosravi (2012) investigated the effect of inflation on investment in private sector. The results of the research show that investment in state sector, inflation, tax on the companies and the rate of interest have had a negative relationship with investment in private sector, but loans, moderating policies and the fund of foreign exchange saving have had a positive effect on the investment in private sector. Regarding the reversed relationship between investment and inflation applying effective policies on reducing the inflation would cause encouraging to save and creating motives for investment, preventing capital escape from manufacturing sector to mediating and stock jobbery activities.

Hakimi (2013) investigated the mechanism of motivation of investment process by taxes in the industrial companies of Islamic Republic of Iran, the reformation of direct taxes law that was proved by the Islamic Council Parliament in 1380 and concluded that ignoring the conditions before reformation and the present tax exemptions in industry, the new law hasn't had any effective role in the rate of investment and in contrary, factors such as the rate of bank interest, the rate of growth in dwelling price and so on has been relatively more effective.

Abdolmaleki and Shirdelan (2013) did a research as "investigation of the effect of tax exemptions on the regional economic efficiency (a case study on tax exemptions in poor areas the topic of provision 132 of the law of tax exemptions. The results show that the factor of tax exemptions didn't have any effect on the average rate of economic growth and development in the provinces of the country and it can be because of the power of motivating this policy, shortage of the time period to run this law, lack of sensitivity to investment and manufacturing in the areas to tax laws, lack of simultaneous factors in order that the tax exemption be effective or lack of important factors for the effectiveness of the factor of tax exemption.

Feyz (2014) analyzed the effective factors on the efficiency and effectiveness of the structure of exemptions and motives in Semnan province. Tax motives and exemptions is a policy through which the governments behave with discrimination to a group of investors or economic activists (purposeful encourager) or to all of them (public or unpurposeful encourager) in order to get the developmental goals, increasing investment and increasing employment and they do it by giving kinds of discount, preferences, leniency, tax delays and credit. One of the most important problems between the people and the governments is getting the tax. This issue even causes misconception and gap between the public people and the ruling class. The amount of tax, kind of behavior to tax payers, un-purposfulness of the tax exemption are of the issues that can strengthen the feeling of discrimination and injustice among people. Therfore, the principle of justice that is a criterion in the Islamic system should be considered in both tax principle and tax motives for all aspects of individual and social life of the people. Tax encourager is usually given in order to attract the capital. Even though the encouragers have different applications such as regional support, partly and in group, the results show the lack of effectiveness or little effectiveness of it. Beside the doubts that is about the effectiveness of these tax policies in getting the goals of the governments, the gradual joining of the countries in the world to the organization of global business and forcing them to reduce and clear the financial and nonfinancial supports of the industries and companies, has made many countries in the world to review their tax policies and especially their tax encourager. Nowadays, many countries and international organizations such as Universal Bank and the International Fund of Money emphasize 0 the reduction of the tax encouragers and making them purposeful and even these two international money organizations have conditioned many of their loans and aids to reduction or elimination of tax encouragers. Although the tax exemptions and subsides are effective in encouraging the activities, but based on the financial experts, the encouragers' policies and tax exemptions have been inefficient in meeting the goals.

Ann Qoye (2000) also investigated the effect of tax encouragers on external direct investment in Tanzania. In her idea, even though tax encouragers may result in increasing the direct external investment but it will deprive the government of a part of future incomes. So, it is necessary that the tax encouragers are applied suitably as much as possible, it means that they should be done in a way that the entering of the direct external investment resulting from it would lead to the increase in the growth and consequently in increasing the tax incomes.

Vorgara (2004) has studied the effects of policies of reducing the tax rate of the income for legal people on the capital performance of Chile in an empirical research. He has gotten this result both in great and small analysis that reducing the rate of tax on the companies has been one of the reasons of investment growth in private sector during the late 1980s in Chile. Great data related to the period between 1975-2003 has showed that reforming the tax structure of Chile and reduction of the tax rate on legal people has improved the investment rate in private sector. Also, small data related to 88 companies during 1988-2003 has proved this result.

Ifert (2010) states in his research that supervising reformations and tax exemption in different industries in relatively poor countries that have good ruling conditions would result in the increase of economic growth.

Ebrahim Heydar (2011) has studied the reformations in working environment, tax system and tax exemption and 
economic growth in 271 countries of the world in a 20-year period. The results if his research shows that reformations in job environment has a positive and meaningful relationship with economic growth of the companies.

Oyleri (2011) has got to this result in his research that generally the taxes don't have a considerable effect on the economic growth and development while little changes in energy and wages have important effects on economic growth. But in contrary, Arnold et, al. (2011 resulted that it is possible to compensate part of the damages of western financial crisis and also meet the long term growth of economy. Levin (2012) also believes that tax policies would affect the economic growth by transfer in investment tendencies and changing the conditions of financial contracts. Repti and Kron (2013) about the effects of tax exemptions on the growth have known the role of long term exemptions very considerable in the growth emphasizing the effect of long term imbalanced distribution of incomes on the economic growth.

\section{Methodology}

In this research, the questionnaire method is used to collect the data. This is of the most popular methods in data collection in survey and field studies. Questionnaires are of the most crucial resources for collecting data and planning the questions and answers is done based on Likert scale.

Likert scale is an interval scale that is made of some phrases and alternatives as answers. So, likert scale is a compound scale that its answer choices usually shows the amount of agreement or disagreement to a topic or concept whether it is positive or negative. There are usually 5 alternatives for each question and each answer has a special score. The following questions have been classified in planning the questions in this research.

\begin{tabular}{|c|c|c|c|c|c|}
\hline Very low & Low & Average & High & Very high & Answer \\
\hline 1 & 2 & 3 & 4 & 5 & Grade \\
\hline
\end{tabular}

\section{Statistic Population and Sample}

Respecting the point that the goal of this research is to identify the amount of the effect of tax exemption of the provision 132 of the law of direct taxes in attracting investment in private sector in industry (industrial towns), so the related society is all the authorities of the investor manufacturer companies in private sector of these companies. Regarding the spread of these companies, not access to the authorities of these companies, the problems related to sending, collecting and returning of the questionnaire from their authorities and the time limit if the research the statistic society that is the goal and the sampling framework related to the research topic are the selected manufacturing investor companies in industrial sites of Eshtehard, Ahams Abad of Tehran and Shokoohiye of Qom that have a great role in attracting and investing more on the private and industrial sector. The considered year is also 2015 when the mentioned questionnaire will be completed.

Statistic sample will be calculated using sampling formula of the infinite society at the error level of $5 \%$. Sampling formula is as follows:

$$
\begin{aligned}
& n=\frac{Z_{\frac{\alpha}{2}}^{2} S^{2}}{d^{2}} \\
& \text { Where : } \\
& \text { n: the number of statistic sample, } \\
& Z_{\frac{\alpha}{2}}^{2}: \text { is the certainty interval, } \\
& \mathrm{S}^{2}: \text { sample variance, and } \\
& \text { e: is the expected error level. }
\end{aligned}
$$

\section{Data Analysis Method}

The researcher should start data analysis after he/she collected and classified the data. It is an important stage in the research because it shows the many efforts the previous researchers have had done in the field. In this stage, the researcher investigates the information and data in order to test and evaluate the research hypotheses.

What is important in analyzing data is that the researcher should analyze the information and data in the path of the research goal, responding the research questions and also evaluating the research hypotheses (Hafez Nia, 2006).

The method of comparing the means using SPSS software is used in this research to test the hypotheses.

Test of mean comparison : This method is used to test the assumption about the mean of a society. This test is 
used to investigate the research hypotheses and analyzing the professional questions related to them in most researches that are done by Likert scale.

Testing the normality of data: This test is a simple non-parameter method for identifying the homogeneity of empirical information with the selected statistic distributions.

The zero hypothesis that is tested here is distribution of observations and a clear distribution with a definite parameter that the researcher believes with different guesses and evidence that distribution of the observations does not match those clear distributions (Azar and Momeni, 2008). If the distribution of the data is normal the parametric method and if they are not normal the non-parametric methods are used to test the hypotheses. In the present study the normality of the data is tested at first by Kolmogorov-Smirnov test. The zero hypothesis and the contrary hypothesis in order to investigate the data area as follows:

$\mathrm{H}_{0}$ : distribution of the data is normal.

$\mathrm{H}_{1}$ : distribution of the data is not normal.

If the amount of $p$-value $<0.05$ it means that the data is normal; otherwise the data is not normal.

\section{Data Analysis and Results}

\subsection{First main hypothesis}

The first main hypothesis as is follows: "Tax exemption of the provision 132 of the law of direct taxes is effective in increasing investment in private sector in industrial sites."

The results of testing this hypothesis using the method of comparing the means of population have been given in the following tables.

Table 1: Results of testing the first main hypothesis

\begin{tabular}{|c|c|c|c|c|}
\hline Sig. & T-statistics & Standard deviation & mean & \\
\hline 0.000 & 6.86 & 0.683 & 3.46 & First main hypothesis \\
\hline
\end{tabular}

In order to see whether the hypothesis is under investigation is meaningful, the meaningful level of $t$ statistic should be less than error level of the test (here 5\%). As it is observed, the significance level is 0.000 and is less than error level of $5 \%$. Therefore, this hypothesis is accepted and it can be said that tax exemption the topic of provision 132 of the law of direct taxes is effective in the amount of investment of private sector in industrial sites. The mean of the given responses to the questions related to the test of this hypothesis is also 3.46 and it shows that in the idea of most respondents, tax exemption of provision 132 of the law of direct taxes has an effect moe than the average level (point 3) in increasing the amount of investment in or private sector in industrial sites.

\subsection{Second main hypothesis}

The second main hypothesis is a s follows: "Tax exemption of provision 132 of the law of direct taxes has an effect in increasing the amount of investment in private sector in industrial sites of less developed countries."

The results of testing this hypothesis using the method of comparing means in a society have been given in the table 2.

Table 2: Results of testing the second main hypothesis

\begin{tabular}{|c|c|c|c|c|}
\hline Sig. & T-statistics & Standard deviation & mean & \\
\hline 0.000 & 12.51 & 0.774 & 3.98 & Second main hypothesis \\
\hline
\end{tabular}

As it is observed, the significance level is 0.000 and is less than error level of $5 \%$. Therefore, this hypothesis is accepted and it can be said that tax exemption of provision 132 of the law of direct taxes is effective in increasing the amount of investment in private sectors in industrial sites at less developed areas. The mean of given responses to the questions related to testing this hypothesis is 3.98 and it shows that in the idea of most respondents, tax exemption of provision 132 of the law of direct taxes has had an effect more than the average level (point 3) in increasing the investment in private sector in industrial sites in less developed areas. 


\subsection{First sub-hypothesis}

The first secondary hypothesis is as follows: "Reforming the time covering of tax exemption of provision 132 of the law of direct taxes from the government causes an increase in the investment at private sector in industrial sectors."

The results of testing this hypothesis using comparing the means method of a society is given in table 3 .

Table 3: Results of testing the first sub-hypothesis

\begin{tabular}{|c|c|c|c|c|}
\hline Sig. & T-statistics & Standard deviation & Mean & \\
\hline 0.000 & 14.96 & 0.67 & 4.02 & First sub-hypothesis \\
\hline
\end{tabular}

As it can be seen, the significance level of $t$ statistic is 0.000 and it is less than error level of $5 \%$. So, this hypothesis is accepted and it can be said that reforming the time covering of tax exemption of the topic of provision 132 of the law of direct taxes from the government causes an increase in investment in private sector in industrial sites. The mean of the given responses to the questions related to testing this hypothesis is 4.02 and shows that most respondents believe that reforming time covering of tax exemption the topic of provision 132 of the law of direct taxes from the government had an effect more than the average level (point 3) on increasing the investment in private sector in industrial sites.

\subsection{Second sub-hypothesis}

The secondary hypothesis 2 is as follows: "Enjoyment of industrial sites located in the identified radius in note 2 of provision 132 of the law of direct taxes from tax exemption of the mentioned provision causes an increase in private investment in industrial sites."

The results of testing this hypothesis using the method of comparing the mean of the society is given in table 4 .

Table 4: Results of testing second sub-hypothesis

\begin{tabular}{|c|c|c|c|l|}
\hline Sig. & T-statistics & Standard deviation & mean & \\
\hline 0.000 & 12.88 & 0.622 & 3.81 & Second sub-hypothesis \\
\hline
\end{tabular}

As it is observed, the meaningful level of t statistic is 0.000 and is less than error level of $5 \%$. Therefore, this hypothesis is accepted and it can be said that enjoyment of the industrial sites located in the identified radius in note 2 of provision 132 of the law of direct taxes from tax exemption in mentioned provision causes an increase in private investment in industrial parts.

The mean of he given responses to the questions related to testing this hypothesis is also 3.81 and shows that in most respondents' opinion reforming the location radius of tax exemption the topic of provision 132 of the law of direct taxes had an effect more than the average (point 3 ) in increasing the amount of private investment in industrial sites.

\subsection{Third sub-hypothesis}

Third secondary hypothesis is as follows: "Reforming the source of calculating the exemption topic of provision 132 of the law of direct exemptions from the tool benefit to the interest will be applied by the identified tax will cause efficient enjoyment of the mentioned exemption."

The results of testing this hypothesis using the method of comparing the means of a society are given in table 5 .

Table 5: Results of testing the testing third sub-hypothesis

\begin{tabular}{|c|c|c|c|c|}
\hline Sig. & T-statistics & Standard deviation & Mean & \\
\hline 0.000 & 20.44 & 0.497 & 4.03 & Third sub-hypothesis \\
\hline
\end{tabular}

As it is seen, the significance level is 0.000 and is less than error level of $5 \%$. So, this hypothesis is accepted and it can be said that reforming the source of calculating the exemption of the topic of provision 132 of the law of direct taxes of the tool profit to the interest undergoes the identified tax will cause an efficient enjoyment of the mentioned exemption. The mean of given responses to the related question to this hypothesis testing is also 4.03 and shows that in most 
respondent's idea reforming the source of calculating the exemption the topic of provision 132 of the law of direct taxes had an effect more than average (point 3) in increasing the amount of private investment in industrial sites.

\section{Ranking the Factors of Tax Exemption}

Freidman ranking test was used in order to see which of the classified activities is more important. The results of Freidman test are in table 6.

Table 6: Freidman test for ranking the factors of tax exemption

\begin{tabular}{|c|c|c|}
\hline Sig. & Chi-square test & \\
\hline 0.000 & 15.70 & Freidman test \\
\hline
\end{tabular}

If the significance level of Ki-2 statistic is less than error level (5\%), it shows that there is difference according to ranking between the factors under investigation. As it is observed, meaningfulness of Ki-2 statistic is 0.000 that is less than error level of the test. Therefore, there is a meaningful difference based on ranking and importance among three factors including time covering, location radius and the rate of tax exemption. Ranking these factors is given in table 7 .

Table 7: Ranking main factors

\begin{tabular}{|l|c|l|}
\hline Ranking & Average ranking & \\
\hline First & 2.19 & Time covering \\
\hline Second & 2.14 & Location radius \\
\hline Third & 1.67 & Rate of tax exemption \\
\hline
\end{tabular}

As it is observed, the respondents to the questionnaire gave more importance among the factors of tax exemption of provision 132 in increasing and attracting investment to the factor of time covering. After that location radius of the tax is the second factor based on the importance and at the end is the rate of tax exemption as the third factor.

\section{Discussion and Conclusion}

As it is seen, all the hypotheses were accepted based on the statistic test. In all five hypotheses that were tested, the average given responses were more than 3 that means in the respondents' opinion the mentioned factors have a meaningful effect in attraction and increasing investment in private sector. In relation to tax exemption also three factors of time covering of tax exemption, the radius of location of tax exemption and the source of calculating tax exemption were discussed. For this purpose, the respondents were asked to identify their priority in relation to effectiveness of each of these factors to increase and attract investment in private sector. As the result, the respondents to this questionnaire gave the most importance to the factor of time covering among the factors of tax exemption of provision 132 in increasing and attracting investment. Then, the radius of the location is the second important factor and at last the rate of tax exemption is the third factor.

\section{Recommendations of the Study}

As it was stated, the results of the research generally showed that tax exemption of provision 132 of the law of direct taxes and its factors have a meaningful effect in increasing and attracting the investment in private sector. For this reason, the following suggestions are given:

It is suggested to the legislators and official officers of the organization of tax issues and the industry part of the country to consider more time covering for tax exemptions of industrial sites. big cities.

First, it is suggested to consider tax exemption of provision 132 of the law of direct tax for the industrial sites near

Second, the increase in rate and resource of calculation of tax exemption of provision 132 of the law of direct tax and more acceptances of the expenses of establishment and running is very effective in the attraction of private investors. So, doing some reformations in this field can be effective.

Third, doing reformations and making the field suitable for the private investors through tax exemptions can cause 
more job opportunities in addition to the cooperation in private sector and increasing the efficiency in industry and manufacturing in the country.

\section{References}

Abdolmaleki, H., \& Shirdelan, Sh. (2013). Analysis of efficiency of regional economic impact of tax cuts, Quarterly Journal of Tax, 20.

Abdolmaleki, H., \& Shirdelan, Sh. (2013). Analysis of the impact of tax exemptions on regional economic efficiency: A case study tax exemptions deprived areas referred to in Article 132 of BC). Tax Journal, 68, 169-198.

Aizenman,J., \& Marion, N. (1995).Volatility, Investment and disappointment aversion .NBER Working paper, № 5363.

Arnold, J.M. (2011). Tax Policy for Economic Recovery and Growth, The Economic Journal, 121, 59-80.

Avinash. D., \& Pindyck,R. (1994). Investment under uncertainty, Princton University Press, Princton, New Jersey.

Feyz, A. (2014). The analysis of the factors affecting the efficiency and effectiveness of the exemptions and tax incentives in the province, MS Thesis, University of Ferdowsi.

Hakimi (2013). The mechanism by taxes stimulate investment process in industrial companies of Iran. Accounting and Auditing Research, 18.

Hornby, A. S. (2001). Oxford Advanced Learner's Dictionary of Current English. 6th Ed, Oxford University Press.

Ibrahim Heidar, L. (2011). The Impact of Business Regulatory Reforms on Economic growth.

Kalpper, L., \& Inessa, L. (2012). The Impact of Business Environment Reforms on New Firm Registration.

O'Leary, S. ( 2011). Economic Development and the Business Personal Property Tax ,Conference of Southern County Associations ,www.wvpolicy.org.

Repetti, R. J. \& Caron, P. (2013). Occupy the Tax Code: Using the Estate Tax to Reduce Inequality and Spur Economic Growth, University of Cincinnati - College of Law, 40 (5).

Vergara, R. (2004). Taxation and private investment : Evidence for Chile .available at: ssrn.com. 